\title{
Fishery and life history of spot-tail mantis shrimp, Squilla mantis (Crustacea: Stomatopoda), in the Gulf of Cadiz (eastern central Atlantic)
}

\author{
YOLANDA VILA, IGNACIO SOBRINO and Mª PAZ JIMÉNEZ \\ Instituto Español de Oceanografía, Centro Oceanográfico de Cádiz. Puerto Pesquero, Muelle de Levante, s/n, 11006 Cádiz, \\ Spain. E-mail: yolanda.vila@cd.ieo.es
}

\begin{abstract}
SUMMARY: Squilla mantis is an economically important species that is mainly caught by the Sanlucar de Barrameda bottom trawl fleet in the Gulf of Cadiz (eastern central Atlantic). Annual landings have ranged between 24 t in 1999 and 600 $\mathrm{t}$ in 2003, with a mean value of $269 \mathrm{t}$ for the period 1984-2010. Catches have a marked seasonality, peaking in winter and showing the lowest values in summer. Larval abundance was negatively correlated with depth and distance from the coast but positively correlated with sea surface temperature. No correlation with sea surface salinity was found. The highest larval abundance was observed in June at 20-25 m depth, while adults were mostly found at 30-35 m depth. This species is mainly concentrated in the area of influence of the Guadalquivir River but is very scarce in the rest of the study area. The maturation of the ovary and the activity of the sexual accessory glands begin in early winter. The population is age-structured in three year classes and females reach first maturity within the second year class, at $23.7 \mathrm{~mm}$ carapace length.
\end{abstract}

Keywords: Squilla mantis, fisheries, maturation, larvae, Gulf of Cadiz.

RESUMEN: Pesquería e historia de vida de la galera, Squilla mantis (Crustacea: Stomatopoda) en el Golfo de Cádiz (Atlántico Centro-oriental). - La galera Squilla mantis es una especie de importancia económica en el Golfo de Cádiz (Atlántico Centro-oriental), capturada principalmente por la flota de arrastre de fondo de Sanlúcar de Barrameda. Los desembarcos anuales oscilaron entre 24 t en 1999 y 600 t en 2003 con un valor medio de $269 \mathrm{t}$ en el periodo comprendido entre 1984 y 2010. Las capturas tienen una marcada estacionalidad, con un pico máximo en invierno y registrándose los valores más bajos en verano. La abundancia de larvas está negativamente correlacionada con la profundidad y la distancia a costa, mientras que una correlación positiva con la temperatura superficial del mar fue encontrada. No se encontró ninguna correlación con la salinidad superficial. Las mayores abundancias de larvas fueron observadas en junio en estaciones situadas a una profundidad de 20-25 m, mientras que los adultos fueron más abundantes a 30-35 m. Esta especie está principalmente concentrada en el área de influencia del río Guadalquivir, y es muy escasa en el resto del área de estudio. La maduración del ovario y la actividad de las glándulas sexuales accesorias comienzan a principio del invierno. La población está estructurada en tres clases anuales de edad, y las hembras alcanzan la primera madurez sexual dentro del segundo año, que corresponde con una longitud del cefalotórax de $23.7 \mathrm{~mm}$.

Palabras clave: Squilla mantis, pesquería, maduración, larvas, Golfo de Cádiz.

\section{INTRODUCTION}

The Gulf of Cadiz lies in the eastern central Atlantic, between Europe in the north and northern Africa in the south. The Spanish South Atlantic Region, which stretches along $303 \mathrm{~km}$ from the mouth of the Guadiana River in Ayamonte, Huelva to Tarifa, Cadiz, is included in the Gulf of Cadiz. For the purposes of the Council
Regulation (EEC no. 3094/86), this region belongs to ICES Subdivision IXa-South. The geographical boundary of this statistical subdivision is delimited by the meridians $7^{\circ} 19^{\prime} \mathrm{W}$ and $5^{\circ} 36^{\prime} \mathrm{W}$ and the parallels $37^{\circ} \mathrm{N}$ and $36^{\circ} \mathrm{N}$. Bio-ecologically, this area sustains a fairly high biodiversity similar to that observed in subtropical regions, leading to the development of extremely diverse patterns of fishery exploitation (Sobrino et al. 1994). 
Demersal resources in the Gulf of Cadiz have long been characterized by a high diversity of commercial species (fish, crustaceans and molluscs) harvested by a wide variety of fishing gears. A wide range of fleets with very different fishing gears compete for the same resource. The bottom trawl fleet, which is composed of around 200 vessels, catches a great diversity of species, the main target species being rose shrimp Parapenaeus logirostris (Lucas, 1846), hake Merluccius merluccius (Linnaeus, 1758), Norway lobster Nephrops norvegicus (Linnaeus, 1758) and octopus Octopus vulgaris (Lamarck, 1798) (Jiménez et al. 2004). Moreover, the artisanal fishery is markedly multi-gear and multispecific, with a fleet of around 1000 vessels which capture more than 50 commercial species (Sobrino et al. 1994; Silva et al. 2002). Trammelnets are used to catch prawn Melicertus kerathurus, (Forsskål, 1775), wedge sole Dicologlossa cuneata (Moreau, 1881), sole (Solea spp.) and cuttlefish Sepia officinalis (Linnaeus, 1758); gillnets to catch hake; a large number of sparids, handjigs, claypots and pots to catch octopus; and longlines to catch sharks and blackspot seabream Pagellus bogaraveo (Brünnich, 1768).

Squilla mantis (Linnaeus, 1758) is a stomatopod crustacean and has a fairly high economic importance. S. mantis is found in Mediterranean waters and in the Atlantic ocean, between Angola and the Gulf of Cadiz, which is the northernmost distribution area in the Atlantic (Manning 1977). This species is absent from European Atlantic waters other than the Gulf of Cadiz (Maynou et al. 2005). It is found from 3 to $150 \mathrm{~m}$ depth (Abelló and Sardà 1989, Abelló et al. 2002) and has exceptionally been recorded in deeper waters, down to 367 m (Abelló et al. 2002).

Spot-tail mantis shrimp lives in silty sands and sandy muds (Froglia 1996; Atkinson et al. 1997), a type of sediment often found at the mouth of large Mediterranean rivers such as the Ebro, Rhone, Po and Nile (Lewinsohn and Manning 1980, Holthuis 1987) or, as in this case, the Guadalquivir, a large Spanish river flowing into the Atlantic waters of the Gulf of Cadiz.

In the estuarine area of the River Guadalquivir, $65 \%$ of the total S. mantis trawl landings are caught by the bottom trawl fleet, whose main homeport is Sanlucar de Barrameda, close to the mouth of the river. The landings corresponding to the artisanal fleet are almost negligible, representing only 3\% of the total (Silva et al. 2006). Spot-tail mantis shrimp is caught together with other species, such as wedge sole, hake, horse mackerel Trachurus trachurus (Linnaeus, 1758), octopus, cuttlefish and prawn.

The exploitation and local human consumption of the spot-tail mantis shrimp goes back to the 19th century (Muñoz 1972) and it now commands a high market price. However, despite its economic importance in this region, data on its biology and fishery are very scarce. This study shows the first contributions to knowledge of the population of S. mantis in Atlantic
TABLE 1. - General characteristics of the GOLFO surveys: date, bathymetric range and total number of sampled stations

\begin{tabular}{lccr}
\hline Survey & Date & $\begin{array}{c}\text { Bathymetric } \\
\text { range (m) }\end{array}$ & $\begin{array}{r}\text { No. of } \\
\text { stations }\end{array}$ \\
\hline GOLFO-0505 & 24-26 May 2005 & $7-202$ & 30 \\
GOLFO-0605 & 28-30 June 2005 & $7-202$ & 30 \\
GOLFO-0705 & 26-29 July 2005 & $9-205$ & 29 \\
GOLFO-0805 & 23-26 August 2005 & $9-203$ & 30 \\
GOLFO-0905 & 19-21 September 2005 & $7-203$ & 30 \\
GOLFO-1005 & 24-26 October 2005 & $6-200$ & 25 \\
GOLFO-1105 & 14-16 November 2005 & $7-202$ & 30 \\
GOLFO-1205 & 12-14 December 2005 & $6-201$ & 30 \\
GOLFO-0106 & 1-3 January 2006 & $11-211$ & 30 \\
GOLFO-0206 & 21-23 February 2006 & $9-207$ & 25 \\
GOLFO-0306 & 14-16 March 2006 & $10-220$ & 27 \\
GOLFO-0406 & 3-5 April 2006 & $9-204$ & 28 \\
GOLFO-0506 & 8-10 May 2006 & $9-210$ & 30 \\
GOLFO-0606 & 12-14 June 2006 & $9-201$ & 27 \\
GOLFO-0706 & 4-6 July 2006 & $9-206$ & 30 \\
GOLFO-0806 & 1-3 August 2006 & $9-205$ & 30 \\
GOLFO-0906 & 18-20 September 2006 & $9-201$ & 30 \\
GOLFO-1006 & 9-11 October 2006 & $10-209$ & 30 \\
GOLFO-1106 & 7-9 November 2006 & $10-203$ & 30 \\
GOLFO-1206 & 12-13 December 2006 & $9-200$ & 23 \\
GOLFO-0107 & 16-18 January 2007 & $9-200$ & 30 \\
GOLFO-0207 & 6-9 February 2007 & $10-204$ & 29 \\
GOLFO-0307 & 6-9 March 2007 & $8-201$ & 29 \\
GOLFO-0407 & 12-14 April 2007 & $9-202$ & 30 \\
GOLFO-0507 & 30 April-3 May 2007 & $10-203$ & 30 \\
GOLFO-0607 & 18-20 June 2007 & $9-209$ & 30 \\
GOLFO-0707 & 17-19 July 2007 & $8-205$ & 30 \\
GOLFO-0807 & 7-9 August 2007 & $9-204$ & 30 \\
GOLFO-0907 & 4-5 September 2007 & $12-201$ & 11 \\
\hline & & &
\end{tabular}

waters, particularly in the Gulf of Cadiz. The aim is to examine several life history aspects of the spot-tail mantis shrimp population in this area, from the larval phase to the reproductive biology of adults, its distribution area, and fishery and abundance trends over the last 27 years.

\section{MATERIALS AND METHODS}

\section{Larval cycle}

Plankton samples were obtained in monthly surveys carried out from May 2005 to September 2007 (Table 1) on board the R/V Regina Maris (Consejería de Agricultura y Pesca of the Andalusian Government, Spain). Seven transects perpendicular to the coastline were used to sample 30 stations between the mouth of the Guadiana River and the Strait of Gibraltar, from 10 to $200 \mathrm{~m}$ depth. At every ichthyoplankton station, double-oblique plankton hauls were carried out with a bongo net (40 cm mouth diameter, $200 \mu \mathrm{m}$ mesh size). All tows were performed at a speed of 2.5 knots and to a maximum depth of $100 \mathrm{~m}$. In each mouth of the net we placed two independent flowmeters (General Oceanics 2030) to measure the volume of filtered water. Plankton samples were immediately preserved in a $4 \%$ buffered seawater formaldehyde solution. The total eggs and larvae from the ichthyoplankton samples were sorted, identified and counted in the laboratory with a binocular microscope. Ichthyoplankton data were standardized to $100 \mathrm{~m}^{3}$ of filtered water (number 
of eggs or larvae/100 $\mathrm{m}^{3}$ ). CTD (Seabird 19) casts were performed at each of the 30 stations down to about $5 \mathrm{~m}$ above the bottom.

The degree of ecological and taxonomical knowledge of the stomatopod larvae is very limited. Of the approximately 350 known species of stomatopods, only around $10 \%$ can be identified at their larval stages (Díaz 1998). The larval stages of S. mantis have been described by Giesbrecht (1910). The larvae of this species can also be easily identified in our samples, because only two species of stomatopods are present in the area, Squilla mantis and Rissoides desmaresti (Risso, 1916), the latter being very scarce (only a few individuals were caught during the surveys).

The correlation between the spot-tail mantis shrimp larval densities and the biological and physical parameters (zooplankton biovolume, temperature, salinity, distance from the coast and depth) was explored through a pairwise Spearman rank correlation analysis.

In order to characterize the spawning habitats we obtained the quotient plots using the statistical programme "R". Quotient curves are a convenient tool for characterizing the spawning habitat of small pelagic fishes in regard to physical and biological parameters (Drapeau 2005). A quotient curve is a bi-variate curve, considered an exploratory data analysis technique (Lluch-Belda et al. 1991) that describes the "relation shape" between relative abundances of fish eggs and environmental variables such as temperature, salinity, depth and phytoplankton (e.g. van der Lingen et al. 2001). Quotient curves are computed on simple datasets. Datasets should provide egg or larvae abundance and other biological and physical measurements collected from field sampling for all the stations sampled. The curves represent the relative abundances of larvae of $S$. mantis over the whole spectrum of environmental values.

\section{Fishery}

The Spanish Oceanographic Institute (IEO) compiled the fishery activity data from the Spanish fishermen's associations of the main spot-tail mantis shrimp landing ports in the Gulf of Cadiz. Landing data were gathered from January 1984 to December 2010, whereas the fishing effort series (expressed as fishing days) used here started in January 1994.

\section{Distribution and abundance}

Information about the spatial and bathymetric distribution of this species and the length frequency data of the population come from the IEO demersal bottom trawl surveys routinely carried out in the Gulf of Cadiz (ARSA surveys) in spring (every March since 1993) and autumn (every November since 1997). For this study we analysed a total of 33 surveys (18 in spring and 15 in autumn). The surveys sampled an area of
$7224 \mathrm{~km}^{2}$ over the continental shelf and the uppermiddle slope, between latitudes $6^{\circ} 20^{\prime} \mathrm{W}$ and $7^{\circ} 20^{\prime} \mathrm{W}$, and from 15 to $800 \mathrm{~m}$ depth. The surveys were carried out on board the R/V Cornide de Saavedra (IEO), following a random-stratified sampling design with five depth strata (15-30 m, 31-100 m, 101-200 m, 201$500 \mathrm{~m}$ and 501-800 $\mathrm{m}$ ). The number of hauls in each depth stratum was proportional to the trawlable surface adjusted to the ship time available at sea and the haul duration was 1 hour. All hauls were carried out during daylight hours using Baka 40/60 trawl gear with a 43.6 $\mathrm{m}$ footrope and a $60.1 \mathrm{~m}$ headline. An inner $20 \mathrm{~mm}$ codend liner was used to prevent the escape of small individuals. The spatial distribution of the abundance of $S$. mantis was inferred from the historical data series of the surveys and expressed as mean yields (number of individuals per hour). Further information about the methodology of these ARSA surveys is given in the Manual for the International Bottom Trawl Surveys in the Western and Southern Areas by the ICES Working Group on International Bottom Trawls Survey (Revision III) (Anonymous 2010).

The additional information analyzed in this study and concerning the shallowest area $(<20 \mathrm{~m}$ depth) comes from a project for the delimitation of a fishing reserve at the mouth of the Guadalquivir River in 2000 and 2001 (Sobrino et al. 2005). This project carried out monthly trawls between 3 and $20 \mathrm{~m}$ depth.

\section{Population structure}

Size frequency distributions by sex were obtained from the data of surveys from November 2009 to March 2011. To identify the different cohorts in the population we applied the Bhattacharya method (1967) to the length distribution by sex obtained from the ARSA 1109 survey data. The number of cohorts and their corresponding mean carapace lengths (CL) thus obtained were subsequently used as input values in the Hasselblad method (1966) or the NORMSEP (Normal Distribution Separation) (Gayanilo et al. 2005, Hasselblad and Tomlinson 1971). These analyses were performed using FiSAT software (Gayanilo et al. 2005). The Kolmogorov-Smirnov test was used to test significant differences between sexes.

\section{Biological study}

Spot-tail mantis shrimps caught during the bottom trawl survey carried out in autumn 2009 and 2010 (ARSA1109 and ARSA1110) and spring 2010 and 2011 (ARSA0310 and ARSA0311) were sampled for the biological study. The ARSA1109 survey provided spot-tail mantis shrimps which were individually recorded for total length (TL, in $\mathrm{mm}$ ), carapace length $(\mathrm{CL}$, in $\mathrm{mm})$, total weight (W, in $\mathrm{g}$ ) and sex. In surveys ARSA0310, ARSA1110 and ARSA0311 we only recorded CL values, sex and ovarian maturity data. These variables were also taken from the 
individuals additionally sampled in the laboratory in December 2010. TL was measured from the tip of the rostrum to the apices of the submedian teeth of the telson, and CL was taken from the median posterior edge of the carapace to the base of the rostrum. Sex was determined by the presence/absence of penis located at the base of the third pair of pereiopods on the eighth thoracic segment, unless ovaries were conspicuous, thus indicating a female. Maturity was assessed after the macroscopic descriptions of ovarian and accessory sexual gland development (WorthamNeal 2002).

We conducted a series of histological analyses in the ovaries of females at different macroscopic maturity stages. The fragments of the ovarian middle region were fixed for $24 \mathrm{~h}$ in $4 \%$ formaldehyde in phosphate buffer $0.1 \mathrm{M}, \mathrm{pH}$ 7.4. Afterwards, the tissue was dehydrated through increasing concentrations of ethanol and embedded in hydroxyethyl methacrylate. Semithin ( $3 \mu \mathrm{m}$ thick) sections stained with toluidine blue were examined and photographed through a NIKON light microscope. All the images taken from each ovarian section were captured using a video camera connected to the microscope and digitized using NIS system software (version 2.33). To determine the diameter range of the different oocyte types, we used an eyepiece micrometer to measure the largest diameter of at least 20 cells per stage and the ovary section (Quinitio et al. 1993).

A non-linear model with minimum least squares adjustment (Gauss-Newton algorithm) served to estimate CL-TL and CL-W relationship for males, females and both sexes combined, according to the following equation:

$$
\begin{gathered}
T L=a C L^{b} \\
W=c C L^{d}
\end{gathered}
$$

Size at first maturity was only estimated for females. After macroscopic examination of the gonad, all females with ovaries in Stages II and III were considered to estimate the average CL at which $50 \%$ of the females were mature $\left(\mathrm{CL}_{50}\right)$. Data were fitted to a logistic model using a generalized linear model (GLM) with binomial errors:

$$
P_{i}=1-\left(1 /\left[1+\exp \left(e+f C L_{i}\right)\right]\right)
$$

where $P_{i}$ is the relative frequency of mature females and $C L_{i}$ is the size class. Regression parameters $e$ and $f$ were estimated from the data.

CL-TL relationship and size at first maturity were estimated with the INBIO R package (Sampedro et al. 2005), which fits the models and estimates the coefficient of variation for parameters by bootstrapping (Efron and Tibshirani 1993). The bootstrap approach uses resampling techniques to estimate different measures of uncertainty for any statistics.

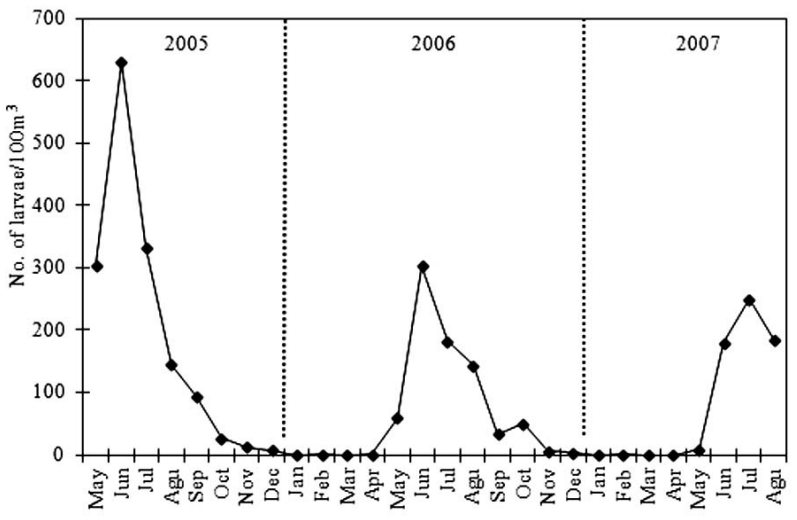

FIG. 1. - Monthly evolution of Squilla mantis larval abundance (no. of larvae $/ 100 \mathrm{~m}^{3}$ ) in the Gulf of Cadiz.

\section{RESULTS}

\section{Larval cycle}

The highest abundance of the $S$. mantis larvae in the study area was observed during the warmer months, showing clear seasonality (Fig. 1). The larvae of this species were present in the study area from May to October. The maximum value of larval abundance was recorded in June $2005\left(630\right.$ larvae/100 $\left.\mathrm{m}^{3}\right)$. In 2006, the larval abundance also peaked in June, but the recorded values were lower (303 larvae $/ 100 \mathrm{~m}^{3}$, approximately). In 2007, the highest abundance was observed a month later, with values close to 250 larvae $/ 100 \mathrm{~m}^{3}$. A decreasing trend in the number of spot-tail mantis shrimp larvae throughout the time series analyzed was observed.

S. mantis larvae were widely distributed over the study area, since they were present at almost all the sampling stations (Fig. 2). However, larvae concentrated at the mouth of the Guadalquivir River, where values at one station attained almost 600 larvae/100 $\mathrm{m}^{3}$ and values at adjoining stations 250 larvae $/ 100 \mathrm{~m}^{3}$. Also, significant larval density values (314 larvae/100 $\mathrm{m}^{3}$ ) were recorded near the coast, at the most coastal station of the transect opposite Cadiz.

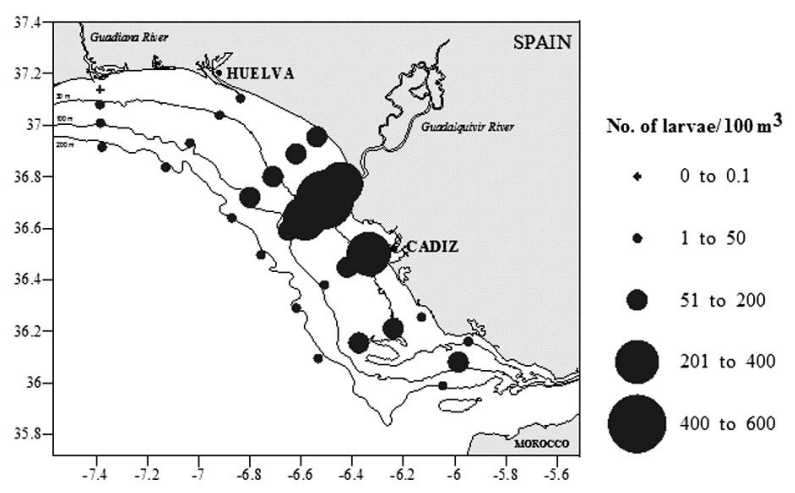

FIG. 2. - Spatial distribution of Squilla mantis larval abundance (no. of larvae/100 $\mathrm{m}^{3}$ ). 


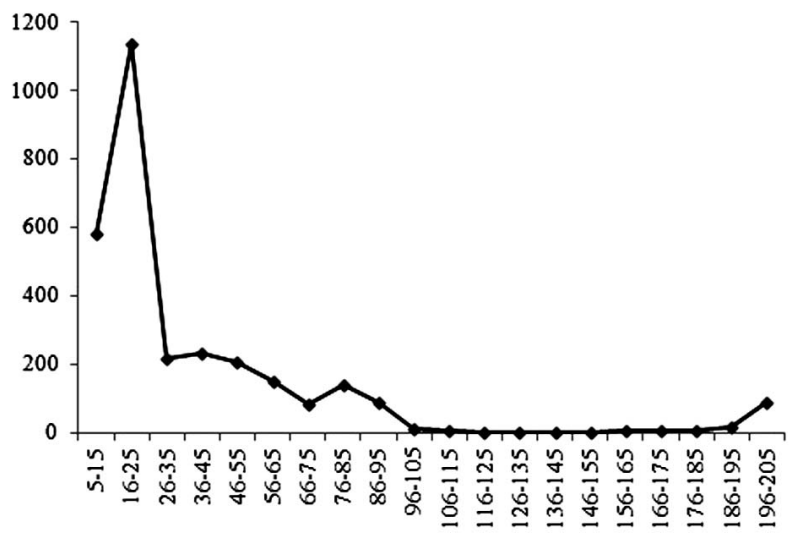

FIG. 3. - Bathymetric distribution of Squilla mantis larval abundance (no. of larvae/100 $\mathrm{m}^{3}$ ).

TABLE 2. - Spearman rank correlation analysis between Squilla mantis larval abundance (no. of larvae $/ 100 \mathrm{~m}^{3}$ ) and ecological parameters. SST, sea surface temperature; SSS, sea surface salinity.

\begin{tabular}{lc}
\hline Factor & Spearman index \\
\hline Station depth $(\mathrm{m})$ & $-0.631^{* *}$ \\
Distance from coast $(\mathrm{m})$ & $-0.569 * *$ \\
SST $\left({ }^{\circ} \mathrm{C}\right)$ & $0.202^{* *}$ \\
SSS & -0.061 \\
Zooplankton volume $\left(\mathrm{m}^{3}\right)$ & $0.502^{* *}$ \\
\hline
\end{tabular}

**Signification level 0.01

Larval abundance of the spot-tail mantis shrimp was negatively correlated with depth and distance from the coast, which tallies with the highest concentration of this zooplankton component observed at most of the coastal stations $(78 \%$ of the larvae were caught within $50 \mathrm{~m}$ depth, Fig. 3). A positive correlation was found between zooplankton abundance and SST range, but no correlation was found with sea surface salinity (SSS) (Table 2).

The ecological importance of the habitat occupied by $S$. mantis is widely known, and from the standpoint of fishing the spawning habitat of this exploited spe-

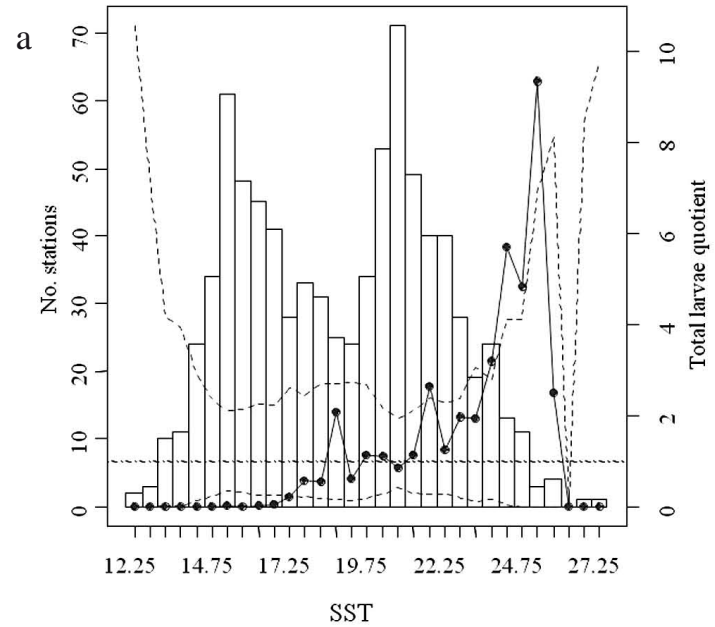

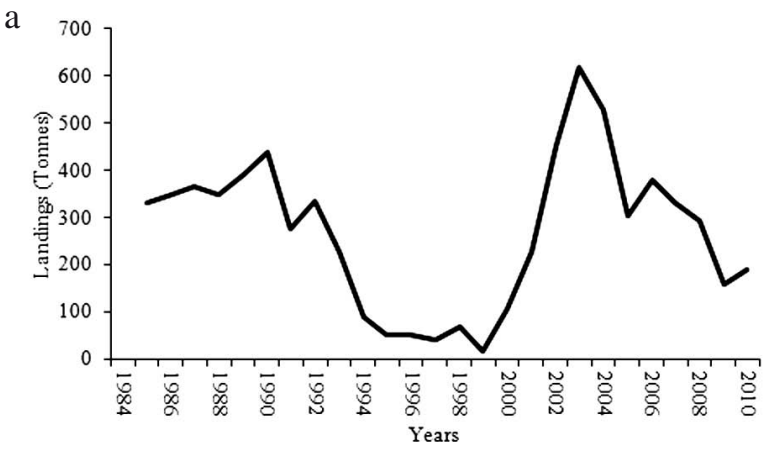

b

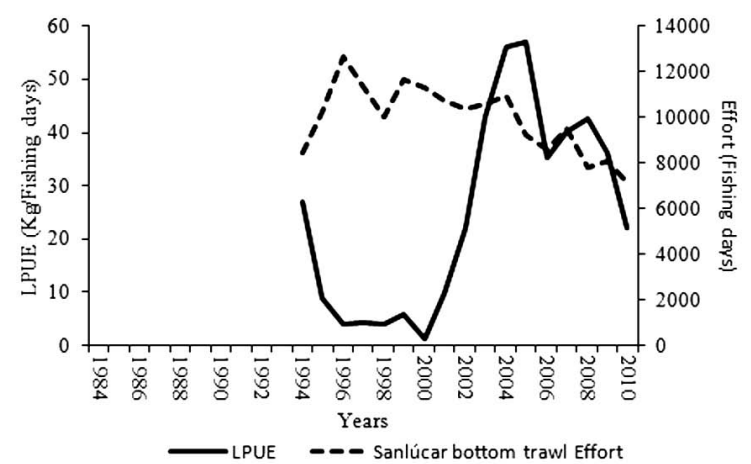

FIG. 5. - Total demersal landings (t) of Squilla mantis from 1984 to 2010 in the Gulf of Cadiz (a) and Sanlúcar de Barrameda bottom trawl fishing effort (fishing days) and landing per unit effort (LPUE, in $\mathrm{kg}$ /fishing days) from 1994 to 2010 period (b).

cies is particularly important. Mantis shrimp larvae showed a statistically significant preference to develop in waters whose SST ranged between $24^{\circ} \mathrm{C}$ and $26^{\circ} \mathrm{C}$ (Fig. 4a). With regard to SSS, no preferred values were statistically significant (Fig. 4b).

\section{Fishery}

Annual landings ranged between $24 \mathrm{t}$ in 1999 and 600 $t$ in 2003, with a mean value of $269 t$ for the 1984-2010

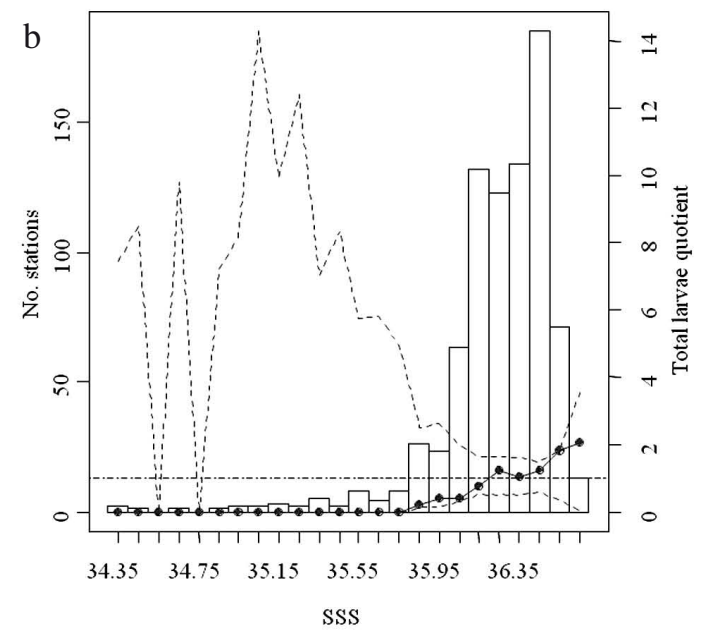

FIG. 4. - Quotient plots of Squilla mantis larval abundance in relation to (a) sea surface temperature (SST) and (b) sea surface salinity (SSS). Dashed lines represent the confidence interval and vertical bars indicate the number of samples taken in each temperature or salinity class. 


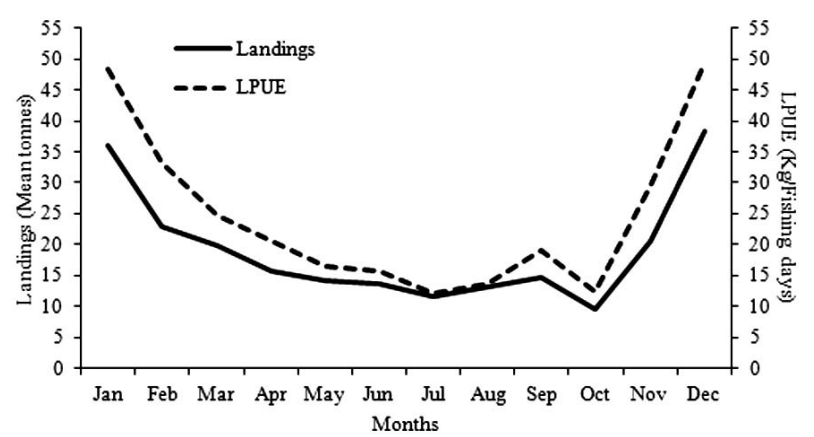

FIG. 6. - Monthly mean landings and LPUE (kg/fishing days) of Squilla mantis in the Gulf of Cadiz.

period. From 1984 to 1992 landings of S. mantis were fairly stable and showed mean yearly values of $350 \mathrm{t}$. However, from 1993 to 1999 landings of this species decreased sharply and catches did not exceed 100 t, reaching a minimum of $15 \mathrm{t}$ in 1999 (Fig. 5a). Subsequently, landings increased to reach a historical maximum of 616 $t$ in 2003 only to decrease again to below $200 \mathrm{t}$ in the last two years of the series. Meanwhile, the bottom trawl fishing effort of the main spot-tail mantis shrimp landing port (Sanlucar de Barrameda) remained stable during the first part of the time series. However, we have noted a gradual decrease in the fishing effort since 2004 (Fig. $5 \mathrm{~b}$ ), probably related to the establishment of a closed season in the framework of the first fishing plan for the bottom trawl fleet in the Gulf of Cadiz. Different fishery management plans have been set up since then, although the number of days of the closed season has decreased in the 2010 plan.

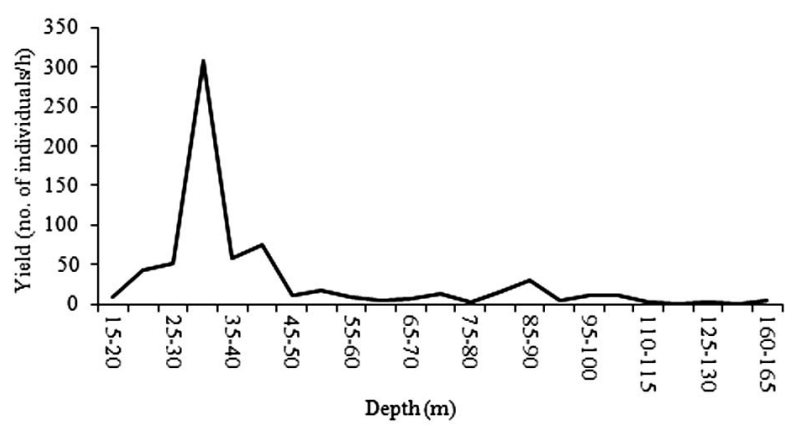

FIG. 8. - Bathymetric distribution of Squilla mantis from bottom trawl surveys (ARSA series).

Landings of $S$. mantis showed a clear seasonal pattern, peaking from late autumn to early spring (Fig. 6). January and December gave the highest landings and yield. The most consistent result for all sets of trawlfishery monthly data for $S$. mantis is that landings and overall landing per unit of effort (LPUE) are positively correlated $\left(r^{2}=0.98\right)$. As shown by Pierce et al. (1994), the absence of correlation between landings and overall effort $\left(r^{2}=0.24\right)$, or between overall LPUE and effort $\left(r^{2}=0.34\right)$, is consistent with a non-directed fishery of a patchily distributed resource, which suggests that overall LPUE (and overall landings) may be used as an index of abundance.

\section{Distribution and abundance}

No differences were observed in the spatial distribution of the abundance of $S$. mantis between the

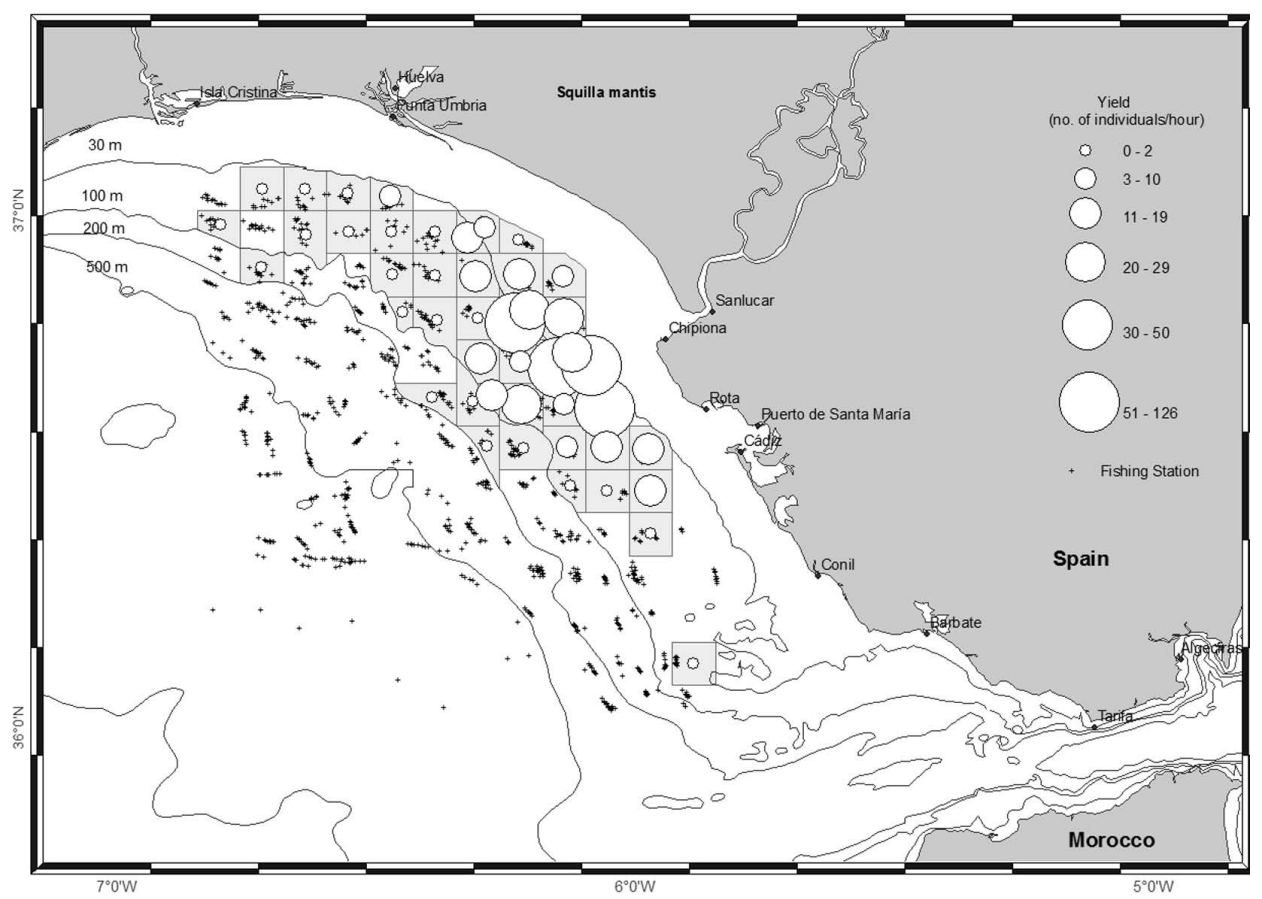

FIG. 7. - Spatial distribution and abundance (mean values of the no. of individuals/hour) of Squilla mantis from bottom trawl surveys (ARSA series). 
Ventral telson
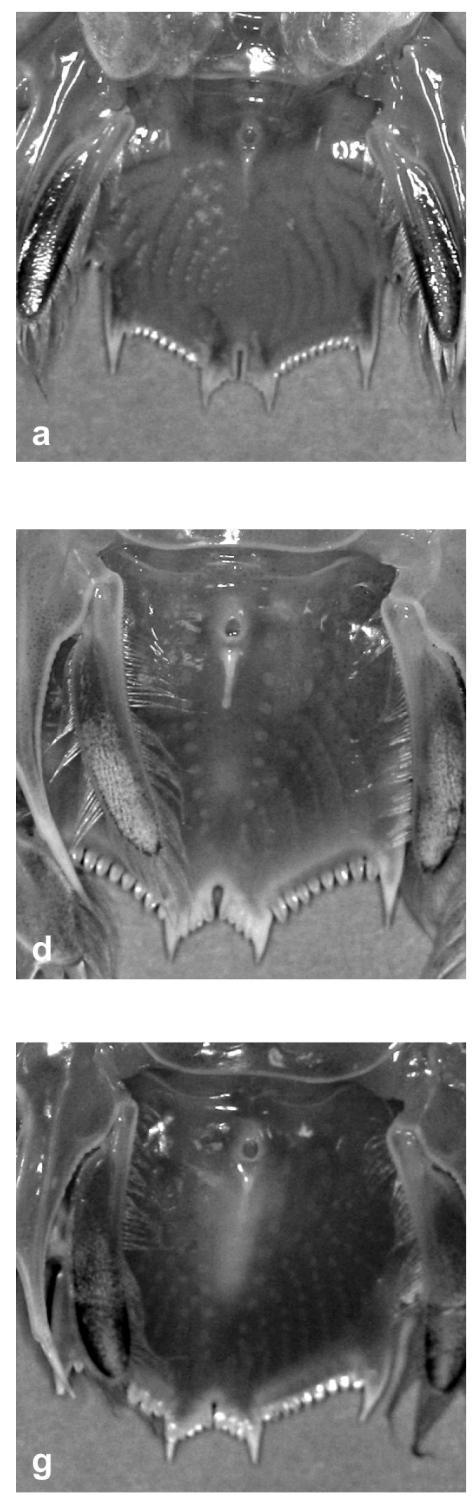

Ventral thoracic

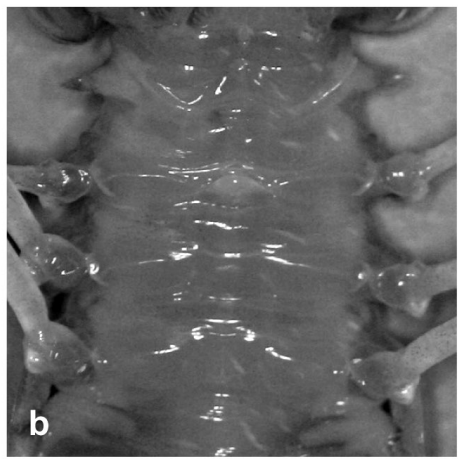

Stage I: Inmature

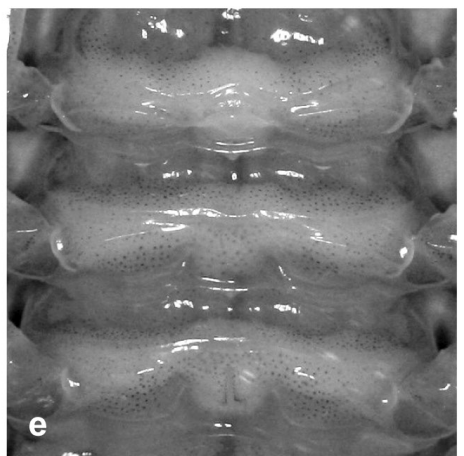

Stage II: Development

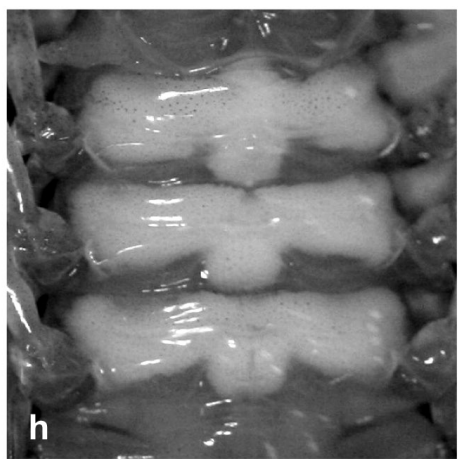

Stage III: Mature

\section{Ovary histology}
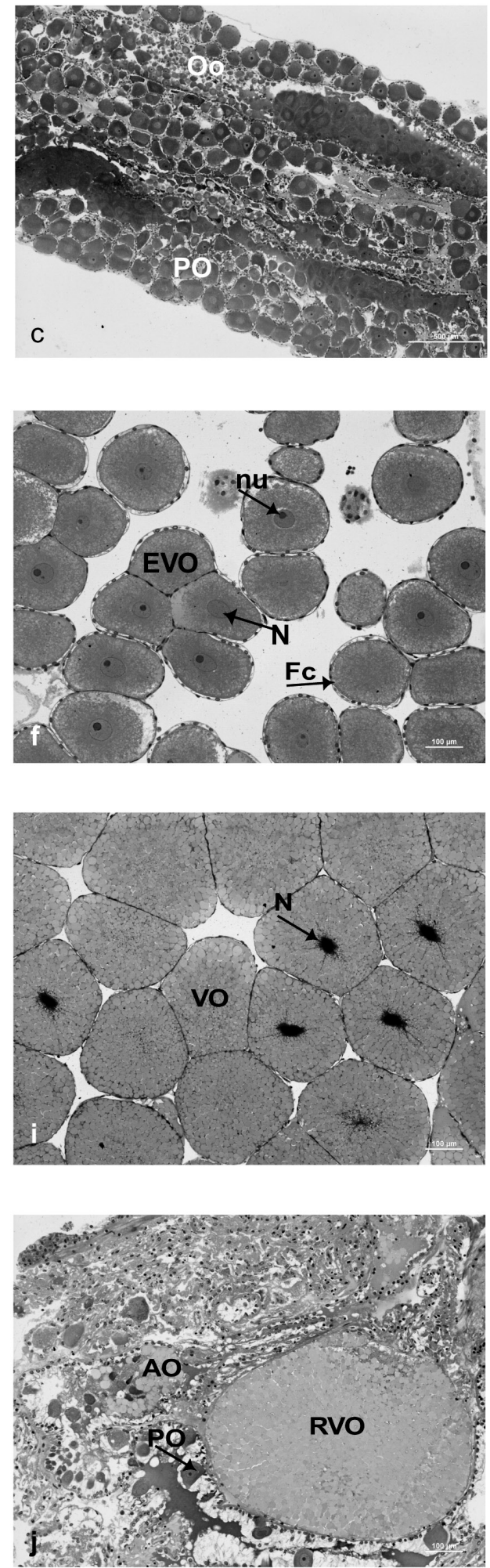

\section{Stage IV: Post-spawning}

FIG. 9. - Ventral telson view, cement gland development and ovarian histology of different maturity stages in females of Squilla mantis. Stage I (immature), a, b, c; Stage II (developing), d, e, f; Stage III (mature), g, h, i; post-spawning, j; Oo, oogonia; PO, previtellogenic oocytes; EVO, early vitellogenic oocytes; VO, vitellogenic oocytes; RVO, residual vitellogenic oocytes; AO, atretic oocytes; N, nucleus; nu, nucleoli; Fc, follicle cells. 
TABLE 3. - Parameters and coefficient of the linear fit between the Squilla mantis abundance indices obtained in the bottom trawl ARSA surveys (March and November series) and landings carried out during the period corresponding to October in year (n) and September in year $(\mathrm{n}+1)$, as well as between both the March and November survey series.

\begin{tabular}{lcc}
\hline Relationship & $\mathrm{a}$ & $\mathrm{b}$ \\
\hline Landings (t) vs yield March survey $(\mathrm{g} / \mathrm{h})$ & 147.43 & 0.3266 \\
Landings (t) vs yield November survey $(\mathrm{g} / \mathrm{h})$ & -136.6 & 0.0279 \\
Yield (g/h) March survey vs yield (g/h) November survey & 137.09 & 0.3401 \\
\hline
\end{tabular}

ARSA surveys carried out in November and March, suggesting that the habitat of the spot-tail mantis shrimp is not modified by season. This species is mainly concentrated in the area of influence of the Guadalquivir River and is very scarce in the rest of the study area (Fig. 7).

Regarding the bathymetry, the ARSA survey data series showed that this species occurs between 15 and $165 \mathrm{~m}$. Most of the individuals were caught from 20 to $45 \mathrm{~m}$, with a peak of abundance between 30 and 35 m (Fig. 8). The monthly trawls at depths between 3 and $20 \mathrm{~m}$ carried out by Sobrino et al. (2005) provided additional data about the shallowest area of occurrence and indicated that the abundance of $S$. mantis increased from $5 \mathrm{~m}$, although with differences between zones.

Taking into consideration the observed seasonality of the fishery, we analysed the relationships between the abundance indices obtained from the ARSA surveys (March and November series) and the landings of October in year $(n)$ and September in year $(n+1)$. We obtained low values of $\mathrm{r}^{2}$ and we observed the presence of points deviating from the general trend (Table 3). No relationship was observed between the March and November surveys (Table 3). Again, these results suggest that spot-tail mantis shrimp landings are the most suitable abundance index for this resource in the Gulf of Cadiz. The fact that the ARSA surveys sampled few stations in the areas of the highest abundance of $S$. mantis may have hindered the estimation of the real abundance of the resource.

\section{Length frequency distributions}

The length distributions obtained in the ARSA1 109 survey (November 2009) were chosen because of the high catch of individuals of both sexes. In November females are more accessible to the trawl gear because they are starting the development of their gonads and are not yet hidden in their burrows, as might occur in March. Table 4 shows the modes of each age class by sex. Two modes were identified with a separation index greater than 2 in males and females corresponding to age classes $1+$ and $2+$. The mean size for the first cohort was approximately $23 \mathrm{~mm} \mathrm{CL}$ for both sexes, whereas the values for the second cohort were $30.8 \mathrm{~mm}$ CL for males and $29.0 \mathrm{~mm}$ CL for females. Sizes ranged between 15 and $35 \mathrm{~mm} \mathrm{CL}$, showed no significant differences between sexes $(p<0.05)$ and the mean CL in each cohort was similar, suggesting that growth is not very different between males and females.
TABLE 4. - Modal size (mm carapace length [CL]) by age (cohort) in the population of Squilla mantis in males and females identified by the NORMSEP method and relative age (months) assigned. June was considered as the month of birth.

\begin{tabular}{ccccc}
\hline Cohort & $\begin{array}{c}\text { Relative age } \\
\text { (months) }\end{array}$ & No. & $\begin{array}{c}\text { Mean } \\
\text { CL } \pm \text { sd }(\mathrm{mm})\end{array}$ & $\begin{array}{c}\text { Separation } \\
\text { index }\end{array}$ \\
\hline $\begin{array}{c}\text { Males } \\
1+\end{array}$ & 17 & 27 & $23.67 \pm 1.80$ & - \\
$2+$ & 29 & 82 & $30.79 \pm 2.30$ & 3.47 \\
$\begin{array}{c}\text { Females } \\
1+\end{array}$ & 17 & 34 & $23.40 \pm 3.37$ & - \\
$2+$ & 29 & 107 & $29.02 \pm 2.20$ & 2.02 \\
\hline
\end{tabular}

\section{Biological study}

The maturation process of spot-tail mantis shrimps was divided into four development stages, based on their external morphological characteristics, the degree of development of the sexual cement glands (which can be observed through the ventral side of the exoskeleton) and the histological observation of the development stage of the most advanced oocytes.

\section{Stage I: Immature}

Immature ovaries are not visible without dissection. Immature females show a monochromatic telson on the ventral side of the telson (Fig. 9a). Gonads are tubular, fine, fragile and translucent. This fact makes it difficult to recognize and separate the ovary from the digestive tract. The cement glands are not visible in the ventral thoracic region (Fig. 9b). Ovaries contain oogonia and previtellogenic oocytes. Two distinct size categories of previtellogenic oocytes can be recognized. The smaller oocytes (20-60 $\mu \mathrm{m})$, located at the centre of the ovary, show a thin cytoplasm surrounding a large nucleus that has a large single nucleole. The larger oocytes (100$150 \mu \mathrm{m})$ have a thicker cytoplasm and are found in the rest of the ovary (Fig. 9c). The follicle cells of the larger previtellogenic oocytes are visible at the periphery of the oocyte.

\section{Stage II: Developing}

Developing ovaries extend along the abdomen and are barely visible through the ventral side of the telson (Fig. 9d). Macroscopically they are yellow and have a granular aspect. The cement glands begin to develop and form three white parallel stripes in the sixth, seventh and eighth thoracic sternites (Fig. 9e). Ovaries are characterized by the presence of early vitellogenic 
TABLE 5. - Parameters of the relationships carapace length vs total length and carapace length vs total weight for males, females and both sexes combined of Squilla mantis. CV, coefficient of variation.

\begin{tabular}{lcccc}
\hline & intercept & slope & CV & No. \\
\hline Carapace length-total length & & & & \\
Males & 6.8586 & 0.8879 & 0.035 & 109 \\
Females & 7.2754 & 0.8766 & 0.041 & 141 \\
Combined & 7.3949 & 0.8693 & 0.027 & 250 \\
Carapace length-weight & & & & \\
Males & 0.006776 & 2.546558 & 0.052 & 140 \\
Females & 0.004347 & 2.672516 & 0.053 & 181 \\
Combined & 0.005118 & 2.626321 & 0.035 & 321 \\
\hline
\end{tabular}

oocytes (200-300 $\mu \mathrm{m})$ (Fig. 9f). Small yolk granules start to appear in the cytoplasm, increasing in size from the periphery of the oocytes. The layer of follicle cells is still well developed at this stage. The nucleuscytoplasm ratio is lower than in stage I, although the nucleus still remains large.

\section{Stage III: Mature}

Mature ovaries are clearly visible through the ventral side of the telson as a median yellow triangular structure, which represents fused ovaries (Fig. 9g). At maturity, vitellogenic oocytes increase in size to attain values between 300 and $1000 \mu \mathrm{m}$. As the vitellogenic oocytes grow, the nucleus becomes smaller and barely visible in most of the oocytes, with an increasing number of yolk granules in the cytoplasm. Follicle cells become thinner and barely visible. The yolk granules are partly fused in the largest oocytes (800-1000 $\mu \mathrm{m})($ Fig. 9h). The cement glands are fully developed and form 3 dense white bands, connected medially (Fig. 9i).

\section{Stage IV: Post-spawning}

A stage easily confused with stage I, since the post-spawning ovaries are not visible through the telson and the cement glands are shrunken and barely visible externally. Ovaries contain post-ovulatory follicles as well as atretic and residual vitellogenic oocytes (Fig. 9j).

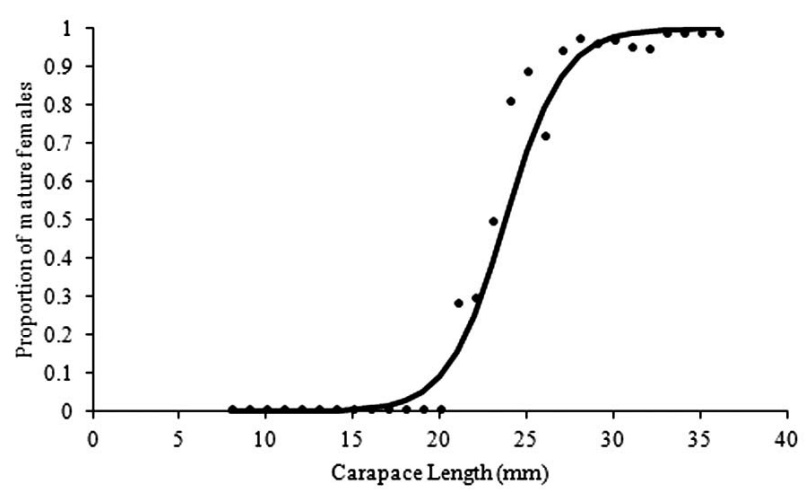

FIG. 10. - Maturity ogive for females of Squilla mantis.
In November, the percentage of the sampled females at the onset of ovarian maturation and development of the cement glands (Stage II) was 38\%, while only $4 \%$ were fully mature (Stage III). Females in Stages II and III increased sharply (almost double) in December, particularly females in Stage II, while the recorded proportion of immature females (Stage I) was the lowest of all the months sampled. In March 2010 the proportion of maturity stages I, II and III was similar (approximately 33\%), although we noted an increase in immature females compared with the previous sampling of March 2011. These results suggest that ovarian maturity peaks and the maximum activity of the cement glands occur earlier in the year.

The first maturity size for females was of $23.7 \mathrm{~mm}$ $\mathrm{CL}(\mathrm{CV}=0.012)$ and ranged between $20.7 \mathrm{~mm}\left(\mathrm{CL}_{25}\right)$ and $26.1 \mathrm{~mm}\left(\mathrm{CL}_{75}\right)$. Figure 10 shows the maturity ogive. For males, the size at first maturity could not be estimated because of the difficulty of identifying the different maturity stages macroscopically.

Table 5 shows the relationships between CL and TL and between CL and W of the spot-tail mantis shrimp for males, females and both sexes combined. Our results evidence a negative allometric growth, since the individuals grow faster in weight than in length.

\section{DISCUSSION}

The life history and fishery of S. mantis have been studied in different areas of the Mediterranean Sea (Do Chi 1975, Froglia 1996, Abelló and Sardá 1989, Maynou et al. 2005), although there are no studies about its biology in Atlantic waters. Our study shows that the results obtained in the Mediterranean Sea and in the Gulf of Cadiz are, overall, concordant.

The presence of larvae from May to September, peaking in June-July during the three years studied, indicates clear seasonality in the spawning period. Considering the observed percentage of females having initiated both ovarian and cement glands development (Stages II and III) and assuming an incubation period of 2.5 months, as established in the Gulf of Napoli by Giesbrecht (1910), spawning takes place between winter and spring in the Gulf of Cadiz. This information corresponds to the findings of other authors in the northwestern Mediterranean Sea (Do Chi 1975, Abelló and Sardá 1989, Maynou et al. 2005).

In comparison with Mediterranean areas, spottail mantis shrimp larvae are observed in the Gulf of Cadiz about a month beforehand. Soro and PiccinettiManfrin (1992) found larvae from July to November in the Adriatic Sea, as did Jacques and Thiriot (1967) in the Gulf of Lyon, with a peak in September. In the eastern Mediterranean, larvae were observed in the same periods but peaking in August (Williamson 1967, Lewinsohn and Manning 1980).

In the Gulf of Cadiz we found a clear and significant relationship between larval abundance and sea surface temperature. The most suitable temperature for the 
presence of $S$. mantis larvae ranged from $24^{\circ} \mathrm{C}$ to $26^{\circ} \mathrm{C}$. The above-mentioned advancement of egg-hatching in the Gulf of Cadiz compared with other Mediterranean areas is probably related to these environmental conditions, even if no information is given about the oceanographic conditions in the studies carried out in the Mediterranean Sea.

The spatial distribution of larvae and adults was very similar and both were clearly associated with the zone of influence at the mouth of the Guadalquivir River.

The duration of the pelagic phase described in other areas of the Mediterranean is from two to three months (Piccinetti-Manfrin 1999). Demersal colonization by post-larvae takes place from August to September, corresponding to a length of about 3-4 mm CL for the Mediterranean coast of Catalonia (Maynou et al. 2005). These post-larvae undergo fairly rapid growth. The recruitment to the fishery begins in November and December, and is completed between January and May for individuals measuring $6 \mathrm{~cm}$ TL (11 mm CL) (Maynou et al. 2005). In the Ebro River delta, Abelló and Sardá (1989) found a population of S. mantis structured in three age classes, in which the females reached a medium size of 10-11 mm CL in their first year, 26 $\mathrm{mm} \mathrm{CL}$ in their second year and $32 \mathrm{~mm} \mathrm{CL}$ in their third year. Males reached medium sizes of 8, 27 and $36 \mathrm{~mm} \mathrm{CL}$, for the first, second and third age classes, respectively.

According to the peak of larval abundance we set June as the month of birth for this species in the Gulf of Cadiz. After two or three months of pelagic phase, as observed by Piccinetti-Manfrin (1999) in the central Mediterranean and by Maynou et al. (2005) along the Catalan coast, the benthic settlement of the post-larvae would occur in September. The size distribution data from the ARSA1109 survey (November 2009) proved the presence of only two annual classes. Taking the month of highest larval abundance as the date of birth, age group 1+ will represent individuals of 17 months (almost 2 years) and sizes of $23 \mathrm{~mm}$ CL for both sexes, whereas age group 2+ will be composed of individuals of 29 months (almost 3 years) and sizes of $29 \mathrm{~mm} \mathrm{CL}$ for females and $30 \mathrm{~mm}$ CL for males. No significant differences were observed between males and females, suggesting that the growth of both sexes is similar.

Therefore, the life span of the spot-tail mantis shrimp is about three years in the Gulf of Cadiz, which coincides with the results of Do Chi (1975) in the north of the Gulf of Lions, Froglia (1996) in the Central Adriatic Sea, and Maynou et al. (2005) and Abelló and Sardá (1989) on the Catalan coast. In the remaining surveys analyzed in this paper we observed individuals measuring below $11 \mathrm{~mm}$ CL, established by Maynou et al. (2005) as the medium recruitment size in the Ebro River delta. However, as the smallest individuals of $S$. mantis live mainly at shallow depths not sampled in the ARSA surveys, the very low frequency of these small specimens captured hindered a clear differentiation of the age class 0 in both sexes. In order to obtain a more accurate estimation of the population structure, as well as an index of the abundance of this resource in the Gulf of Cadiz, a sampling covering the area not trawled by ARSA surveys (stratum $<30 \mathrm{~m}$ of depth) would be necessary.

Our results suggest that the smallest juveniles captured in the autumn and spring surveys correspond to individuals born during the previous summer, according to the observations of Abelló and Sardá (1989) and Maynou et al. (2005) on the Catalan coast. However, in the Gulf of Cadiz the recruitment of spot-tail mantis shrimp to the trawl fishery does not occur during their first year of life. The specimens sampled monthly by the IEO on board commercial vessels to obtain size distributions always measure more than $19 \mathrm{~mm} \mathrm{CL}$, as observed in the landings and the scarce discards of the trawl fleet in the Gulf of Cadiz. This could be due to differences in the fishing gear selected for use in both areas: in the Mediterranean Sea the trawl fleet used a 40-mm diamond mesh during the period analyzed by these authors, whereas the bottom trawl fleet used a 55-mm diamond mesh in the Gulf of Cadiz, according to 2009 regulations.

Size-frequency distributions of the commercial fleet obtained through concurrent sampling on board, based on EU DCR (Data Collection Regulation) (Reg. EC 1343/2007), have been available since 2010. The smallest and largest sizes landed were 19 and $41 \mathrm{~mm}$ CL, respectively. The fishery is therefore exploiting the adult fraction of the population, since size at first maturity was estimated at $23.8 \mathrm{~mm} \mathrm{CL}$ and corresponds to age class 1+. Our result agrees with the findings of Do Chi (1975), Abelló and Sardá (1989) and Maynou et al. (2005), who calculated female size at maturity as between 20 and $25 \mathrm{~mm}$ CL within the second year of life.

The maturation of the ovary and the activity of the sexual accessory or cement glands begin at the onset of winter. These sexual accessory glands secrete a sticky substance composed of an acid-mucopolysaccharideprotein complex that gathers the eggs and protects them (Deecaraman and Subramoniam 1980). These glands develop in synchrony with the ovaries and form dense white patches on the sixth, seventh and eighth thoracic sternites in reproductively active and mature females (Wortham-Neal 2002). Our histological results show that females whose thoracic bands begin to be visible have oocytes with signs of vitellogenesis, according to Do Chi (1975a). This author related the cement gland activity to the vitellogenesis process. This relationship between the development of cement glands and ovarian maturation has been observed in other stomatopods and suggests the existence of an endocrine mechanism of regulation (Deecaraman and Subramonian 1983a). In fact, cement gland activity has been found to be controlled by the same hormones that regulate ovary development (Deecaraman and Subramonian 1983b). Therefore, the temporal activity of the cement glands could be considered as a secondary sexual character 
useful for establishing the spawning season of S. mantis. On the other hand, our histological observations suggest a synchronous development of oocytes into the $S$. mantis ovary, where almost all oocytes are extruded simultaneously, as already observed in other stomatopods (Kodama et al. 2004). Do Chi (1975) reported that each female lays a single batch of eggs giving rise to a single generation per year.

Giesbrecht (1910) described the reproductive behaviour of the spot-tail mantis shrimp females and noted that they remained in their burrows without feeding for more than two months. During this period, females provide care to the egg-mass by using their maxillipedes for cleaning and easing the circulation of water for oxygenation (Wortham-Neal 2002). This behaviour affects seasonal variations in catchability (Piccinetti-Manfrin 1999). Thus, as in other Mediterranean areas (Froglia 1996, Maynou et al. 2005) in the Gulf of Cadiz, the highest catches are observed in late autumn and winter when mating takes place, while the lowest catches are recorded in spring and summer during the incubation period.

The relative proportion of males and females in the catches by season is also observed as a consequence of the reproductive behaviour. Females outnumber males in winter but the sex ratio is biased towards males in spring and summer (Piccinetti-Manfrin 1999, Do Chi 1975, Maynou et al. 2005). A high proportion of females was observed in autumn surveys and in landings of November and December, while a higher proportion of males was observed in spring surveys and in landings of winter and early spring.

Moreover, the nocturnal activity of this species (Froglia and Giannini 1989) has a great influence on its catchability: emergence from burrows usually takes place at night, making this resource less vulnerable to the fishery in areas where night-time fishing is prohibited. In the Gulf of Cadiz one of the technical measures implemented to regulate the fishing effort is a schedule of work to limit daily fishing hours. Though the daily time schedule varies during the year, there are fewer daylight hours in winter and trawlers may therefore operate for longer in hours of darkness in winter, which could increase the catchability of the species.

The spot-tail mantis shrimp is a highly appreciated species in towns located in the most western area of the Gulf of Cadiz. Mature females are kept cold and marketed live and separately from males and immature females because they fetch high prices from December to March, coinciding with the main period of maturation and spawn. This commercial practice has also been observed in the area of the River Ebro delta (Abelló and Martin 1993).

We have also observed a relationship between the landed volumes of spot-tail mantis shrimp and days of swell, which result in a much higher turnover from the bottom. Moreover, changes in environmental conditions could affect mortality in some life-history stages, possibly influencing the relationship between abun- dance of larvae and juveniles (Kodama et al. 2009). However, further studies focusing on the influence of these environmental factors on the $S$. mantis population are needed in order to determine these relationships.

\section{ACKNOWLEDGEMENTS}

We are very grateful for all the help and support from the crew and participants in the ARSA and GOLFO surveys on board the R/V Cornide de Saavedra and R/V Regina Maris. Thanks are also due to Teresa García and $\mathrm{M}^{\mathrm{a}}$ Mar Soriano for their help in the biological sampling and histological processing.

\section{REFERENCES}

Abelló P., Carbonell A., Torres P. 2002. Biogeography of epibenthic crustaceans on the shelf and upper slope off the Iberian Peninsula Mediterranean coasts: implications for the establishment of natural management areas. Sci. Mar. 66(suppl. 2): 183-198.

Abelló P., Martín P. 1993. Fishery dynamics of the mantis shrimp Squilla mantis (Crustacea: Decapoda) population off the Ebro Delta (northwestern Mediterranean). Fish. Res. 16: 131-145.

Abelló P., Sardá F. 1989. Some observations on the biology and fishery of Squilla mantis L. in the Catalan area (NW Mediterranean). In: Ferrero E.A. (ed.), Biology of stomatopods. Mucchi, Modena, pp. 229-239.

Anonymous 2010. Manual for the International Bottom Trawl Surveys in the Western and Southern Areas. (Revision III). In: addendum 2. Report of the International Bottom Trawls Survey ICES Working Group 2010. ICES CM 2010/SSGESST: 06

Atkinson R.J.A., Froglia C., Arneri E., Antolini B. 1997. Observation on the burrows and burrowing behaviour of Squilla mantis (L.) (Crustacea: Stomatopoda). Mar. Ecol. 18(4): 337-359.

Bhattacharya, C.G. 1967. A simple method of resolution of a distribution into Gaussian components. Biometrics 23: 115-135.

Deecaraman M., Subramoniam T. 1980. Cement gland activity in Squilla holoschista; (Crustacea: Stomatopoda); Proc. First All Indian Symp. Invertebr. Repr. 68-76.

Deecaraman M., Subramoniam T. 1983a. Synchronous development of the ovary and the female accessory sex glands of a crustacean, Squilla holoschista. Proc. Indian Acad. Sci. (Anim. Sci.) 92: 179-184.

Deecaraman M., Subramoniam T. 1983b. Endocrine regulation of ovarian maturation and cement glands activity in a stomatopod crustacean Squilla holoschista. Proc. Indian Acad. Sci. (Anim. Sci.) 92: 399-408.

Díaz G. 1998. Description of the last seven pelagic larval stages of Squilla sp. (Crustacea, Stomatopoda). Bull. Mar. Sci. 62(3): 753-762.

Do Chi T. 1975. Biométrie de la reproduction de Squilla mantis (L.) (Crustacé Stomatopode) dans le golfe d'Aigues-Mortes (Méditerranée noroccidentale). Pubbl. Staz. Zool. Napoli 39(suppl.): 114-139.

Drapeau L. 2005. Introduction to the use of quotient curves for characterizing spawning habitat of small pelagic fish. In: van der Lingen C.D., Castro L., Drapeau L., Checkley Jr. (eds), Report of a GLOBEC-SPACC Workshop on characterizing and comparing the spawning habitats of small pelagic fish. Report 21: xii, 33 pp.

Efron B., Tibshirani R. 1993. An Introduction to the Bootstrap. Chapman and Hall, New York, London.

Froglia C. 1996. Growth and behaviour of Squilla mantis (mantis shrimp) in the Adriatic Sea. (EU Study DG XIV/MED/93/016, Final Report).

Froglia C., Giannini S. 1989. Field observations on diel rhythms in catchability and feeding of Squilla mantis (L.) (Crustacea, Stomatopoda) in the Adriatic Sea. In: Ferrero E.A. (ed.), Biology of stomatopods. Mucchi, Modena, pp. 221-228.

Giesbrecht W. 1910. Stomatopoden, 1. Fauna und Flora des Golfes von Neapel 33: 1-239. (Friedländer und Sohn, Berlin).

Gayanilo F.C. Jr., Sparre P., Pauly D. 2005. FAO-ICLARM stock 
assessment tools II (FiSAT II). Revised version. User's manual. FAO Computerized Information Series (Fisheries) 8, 168 pp.

Jacques F., Thiriot A. 1967. Larves de stomatopodes du plancton de la région de Banyuls-sur- Mer. Vie Milieu 18(2): 367-380.

Jiménez M.P, Sobrino I., Ramos F. 2004. Objective methods for defining mixed-species trawl fisheries in Spanish waters of the Gulf of Cadiz. Fish. Res. 67: 195-206.

Kodama K., Oyama M., Lee J.H., Akaba Y., Tajima Y., Shimizu T., Shiraishi H., Horiguchi T. 2009. Interannual variation in quantitative relationships among egg production and densities of larvae and juveniles of Japanese mantis shrimp Oratosquilla oratoria in Tokyo Bay, Japan. Fish. Sci. 75: 875-886.

Hasselblad V. 1966. Estimation of parameters for a mixture of normal distributions. Technometrics 8: 431-444.

Hasselblad V., Tomlinson P.K. 1971. NORMSEP. Normal distribution separator. In: Computer programs for fish stock assessment compiled by N.J. Abramson. FAO Fish. Tech. Pap. 101: 11(1) 2.1-11 (1) 2.10

Holthuis L. B. 1987. Stomatopodes. In: FAO (ed.), Fiches FAO d'identification des espèces pour les besoins de la pêche. Méditerranée et Mer Noire, 1: 181-187. (FAO, Rome).

Kodama K., Shimizu T., Yamakawa T., Aoki I. 2004. Reproductive biology of the female Japanese mantis shrimp Oratosquilla oratoria (Stomatopoda) in relation to changes in the seasonal pattern of larval occurrence in Tokyo Bay, Japan. Fish. Sci. 70: 734-745.

Lewinsohn CH., Manning R.B. 1980. Stomatopod Crustacea from the eastern Mediterranean. Smithsonian Contr. Zool. 305: 1-22.

Lluch-Belda D., Lluch-Cota D.B., Hernández-Vázquez S., SalinasZavalia C.A. 1991. Sardina and anchovy spawning as related to temperaturas and upweling in the California Currenet System. CalCOFI Report 32: 105-111.

Manning R.B. 1977. A monograph of the West African stomatopod Crustacea. Atlantide Rep.12: 1-181.

Maynou F., Abelló P., Sartor P. 2005. A review of the fisheries biology of the mantis shrimp, Squilla mantis (Linnaeus, 1758) (Stomatopoda, Squillidae) in the Mediterranean. Crustaceana 77(9): 1081-1099.

Muñoz J. 1972. La pesca en la desembocadura del Guadalquivir. Observaciones geográfico-humanas sobre la supervivencia de un tipo de pesca. II Premio "José de las Cuevas". Instituto de Estudios Gaditanos. Excma. Diputación Provincial Cádiz, 321 pp.

Piccinetti-Manfrin G. 1999. Squilla mantis. In: Relini G., Betrand
J., Zamboni A. (eds), Synthesis of the knowledge on bottom fishery resources in central Mediterranean (Italy and Corsica). Biol. Mar. Medit. 6 (suppl. 1): 499-502.

Pierce G.J., Guerra A. 1994. Stock assessment methods used for cephalopod fisheries. Fish. Res. 21: 255-285.

Quinitio E.T., Caballero R.M., Gustilo L. 1993. Ovarian development in relation to changes in the external genitalia in captive Penaeus monodon. Aquaculture 114: 71-81.

Sampedro P., Sainza M, Trujillo V. 2005. A simple tool to calculate biological parameters uncertainty. Working Document in Workshop on Sampling Design for Fisheries Data. ICES CM 2005/ACFM:11, Pasajes (Spain), 82 pp.

Silva L., Gil J., Sobrino I. 2002. Definition of fleet components in the Spanish artisanal fishery of the Gulf of Cadiz (SW Spain ICES división IXa). Fish. Res. 59: 117-128.

Sobrino I., Jiménez M.P., Ramos F., Baro J. 1994. Descripción de las pesquerías demersales de la región suratlántica española. Inf. tecn. Inst. Esp. Oceanogr. 151: 1-79.

Sobrino I., García A., García E., Silva L., Baro J., Mas J. 2005. Estudio previo para la delimitación de una reserva de pesca en la desembocadura del Guadalquivir. Junta de Andalucia vol. 76: $1-215$.

Soro S., Piccinetti-Manfrin G. 1992. Stadi larval di stomatopodi in Adriatico. Biol. Mar. Medit. (suppl. Al Notiziario SIBM) 1(1): 71-74.

Van der Lingen C.D., Hutchings L., Merkle D., van der Westhuizen J.J., Nelson J. 2001. Comparative spawning habitats of anchovy (Engraulis capensis) and sardine (Sardinops sagax) in the southern Benguela upwelling ecosystem. In: Cruse G.H., Bez N., Booth T., Dorn M., Hills S., Lipcius R.N., Pelletier D., Roy C., Smith S.J., Witherell D. (eds), Spatial processes and management of marine populations. Univ. Alaska Sea Grant, AK-SG-01-02, Fairbanks, USA, pp. 185-209.

Williamson D.I. 1967. On a collection of planktonic Decapoda and Stomatopoda (Crustacea) from the Mediterranean coast of Israel. Sea Fish. Res. Sta. Haifa Bull. 45: 32-64.

Wortham-Neal J.L. 2002. Reproductive morphology and biology of male and female mantis shrimp (Stomatopoda: Squillidae). $J$. Crustac. Biol. 22(4): 728-741.

Scient. ed.: P. Abelló

Received September 14, 2012. Accepted January 14, 2013.

Published online February 7, 2013. 